\title{
Green Composites in Architecture and Building Material Science
}

\author{
Ruslan Lesovik $^{1}$, Yury Degtev ${ }^{1}$, Mahmud Shakarna ${ }^{1} \&$ Anastasiya Levchenko ${ }^{1}$ \\ ${ }^{1}$ Belgorod Shukhov State Technological University, 308012, Belgorod, Russia \\ Correspondence: Ruslan Lesovik, Belgorod Shukhov State Technological University, 308012, Belgorod, Russia.
}

Received: September 5, 2014

doi:10.5539/mas.v9n1p45

\author{
Accepted: September 8, $2014 \quad$ Online Published: November 23, 2014 \\ URL: http://dx.doi.org/10.5539/mas.v9n1p45
}

\begin{abstract}
Currently, the topic of improvement of man's live ability is becoming increasingly important. The notion of luxury living in the city includes social comfort, environment comfort (urban, natural landscape component). A wide range of small architectural forms of different architectural design and purpose is developed. The basic material for the production of small architectural forms is concrete. On optimal combination of negative and positive qualities, concrete is the most cost- effective material. In order to avoid increasing the price of hardscape, at their creating, it's actual to use local raw materials and industrial waste. On their basis the modern high quality building materials are developed. To reduce prime costs of construction materials the technogenic raw materials are used. The solution of this actual problem possibly on the basis of expansion of a source of raw materials of the stone materials suitable for production of filler. Use of fine-grained concrete is perspective. This look allows to receive high-quality structure of a material, differs high technological effectiveness, allowing it is rather simple to make products as a pressing method with immediate striking, and it is easily and effectively modified by a molding method that is especially convenient for monolithic housing construction, and, besides, by means of organic-mineral modifiers, providing materials with various use of cheap local sand that allows to reduce concrete cost by $15-20 \%$ in comparison with coarse-grained concrete on rubble.
\end{abstract}

Keywords: composite binding, industry wastes, fine-grained concrete, hardscape

\section{Introduction}

For achievement of style unity between architecture and design, and also aim to step aside from aesthetic monotony of large-panel buildings and typical microdistricts, districts of cottage building it is acquired a large amount of hardscapes on the basis of modern building materials, which lead environment to necessary stylistics and mood (Nikolaevskaya, 2002). Decorative elements, well included in landscape (figure 1,2), not only decorate it, but carry a deep meaning (Lesovik, 1994), assisting to system optimization «Man-material-environment» (Lesovik, 2013).

Innovative materials and technologies are the most important basis of "green" construction. The changes happening in the field of development and production of construction materials, already today significantly change construction branch (Mesherin, 2013). Modern materials and decisions allow to reach high rates of energy saving, help to reduce the cost of life cycle of object and as a whole conduct to creation of more comfortable and healthy environment (Mesherin, 2013).

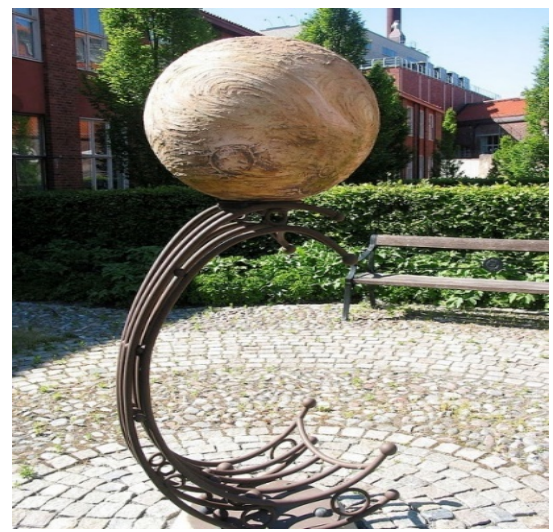

Figure 1. Space themes 


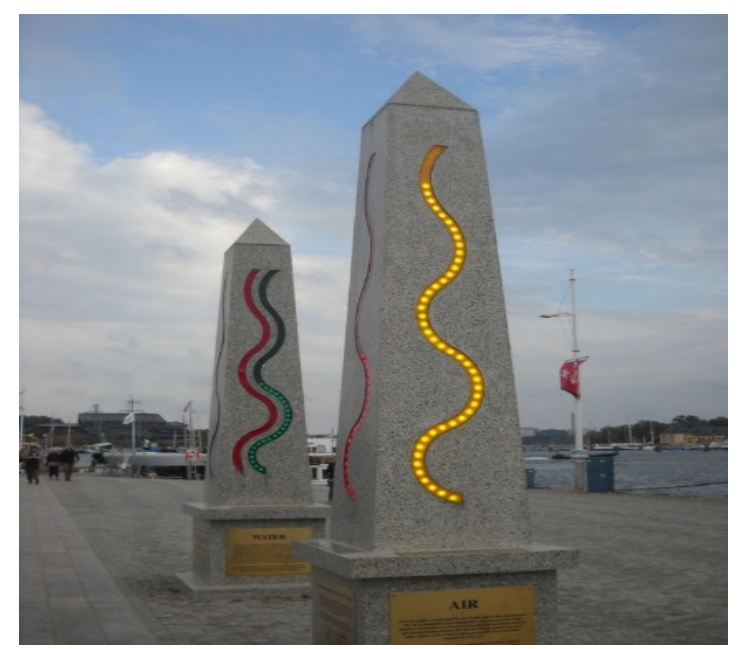

Figure 2. Stele

For increase of interaction efficiency of man`s system and his environment, it's necessary to extend nomenclature and colorness of architecture forms (Lesovik, 2012).

Hardscape (small-scale architecture forms) is separate part of architecture projecting, small constructions, functional and aesthetic constructions, well included in interior (Lesovik, 2013). Each element plays an important role here and has its own place (Nikolaevskaya, 2002).

\section{Materials and Methods}

For the purpose of exclusion of prices increase on hardscape (small-scale architecture forms), at it's creation, it will be actual to use local raw-material, also industry wastes. For getting of small-scale forms and decrease of cost price of building materials, necessary for creation of small-scale architecture forms last achievements in the sphere of building materials science, such as: technogeneous raw materials, composite binding materials, which are produced by combined grinding of CEM I 42,5H cement; wastes of wet magnetic separation of ferruginous quartzites and slags; as fillers - produced overburdens, appearing at production of open casts of ferruginous quartzites; wastes of grinding of rocks on crushed stone and etc. are used (Lesovik, 2012).

The decision of this actual problem is possible on the basis of extension of raw materials base of stone materials, which are suitable for production of filler and use of fine-grained concrete. This kind of building composite allows to get high-quality structure of material, and it has high technology. It also allows to produce goods and products by the method of pressing with immediate striking and by the method of casting. It's very comfortable for monolithic building construction, besides, it is easily and efficiently modified with the help of organ and mineral modifiers, providing materials production with different complex of features. The advantage of it is the use of cheap local sands, that allows to decrease the cost of concrete on $15-25 \%$ in comparison with coarse-grained concretes on crushed stone. Fine-grained concrete allows to get thin-walled and laminated constructions, decorative construction, fibrous concrete, constructions of different materials, products and structures of variable density and series of other effective materials and decisions.

Innovation materials and technologies-the important basis of «green» building. Changes in the field of development and production of building materials, nowadays, considerably varies building branch. Modern materials and decisions allow to reach high rates of energy-saving, help to decrease a cost of life cycle of object and in whole lead to creation of more comfortable and health environment.

The main task of development of green (ecological) building in Russia is decrease of common influence of building on environment and man's health, that is reached at the expense of effective use of energy, water and other resources, also reduce of wastes and other harmful effects.

More over, nowadays, we can see the intensive building which leads to necessity of concretes usage, which have high exploitation characteristics such as: strength on pressing and tension, wear properties, corrosion resistance, crack growth resistance, frost hardiness etc. For decision of this problem, the compounds of fine-grained steel fiber concrete on the basis of technogeneous sand, composite binding materials, micro- dispersed additive and hyperplasticizer were developed (Lesovik, 2012). 
Modern technology, which allows to change the features of concrete materials is disperse reinforcement by fibers, that is introducing into concrete mixture of fibers from different materials: metallic fibers (wiry fibers, produced from melt or chopped from list and etc); basaltic fibers; glass fibers; biological fibers; histic fibers; composite fibers; plastic fibers.

\section{Results}

Perspective direction of efficiency increase if fine-grained steel fibre concrete for production of hardscapes is applying of composite binding materials and high-density packaging of grains of filler. Application of microdispensered additive (in amount 7\% from mass of binding material) and dispersed reinforcement, also optimization of cement stone (at the expense of high-quality packaging of grains of filler), use of super plasticizer allowed to get the resistance at pressing $84,8 \mathrm{MPa}$ (table 1).

Table 1. Physical and mechanical features of fine-grained concrete, reinforced by steel fibre

\begin{tabular}{|c|c|c|c|c|c|c|c|}
\hline $\begin{array}{l}\text { Kind of } \\
\text { binding } \\
\text { material }\end{array}$ & $\begin{array}{l}\text { Binding } \\
\text { material }\end{array}$ & $\begin{array}{c}\text { Sifting of grinding } \\
\text { of quartzitic } \\
\text { sandstone (QS) }\end{array}$ & $\begin{array}{l}\text { Tavolzansky } \\
\text { sand }\end{array}$ & Water & $\begin{array}{l}\text { Steel } \\
\text { wave } \\
\text { fiber }\end{array}$ & $\begin{array}{l}\text { Cube } \\
\text { resistance, } \\
\mathrm{MPa}\end{array}$ & $\begin{array}{c}\text { Resistance, } \\
\mathrm{MPa}\end{array}$ \\
\hline $\begin{array}{l}\text { Cem I } \\
42,5 \mathrm{H}\end{array}$ & 510 & 1180 & 555 & 170 & - & 50,2 & 35,0 \\
\hline $\begin{array}{l}\text { Cem I } \\
42,5 \mathrm{H} \\
* \mathrm{HDP}\end{array}$ & 510 & 1185 & 555 & 172 & - & 56,5 & 38,7 \\
\hline $\begin{array}{l}\text { CemI } \\
42,5 \mathrm{H} \\
\mathrm{Cem} \mathrm{I}\end{array}$ & 510 & 1180 & 555 & 172 & 72 & 57,4 & 39,9 \\
\hline $\begin{array}{l}42,5 \mathrm{H} \\
* \mathrm{HDP}\end{array}$ & 510 & 1185 & 555 & 174 & 72 & 65,2 & 44,9 \\
\hline FPC-70 & 510 & 1180 & 555 & 160 & 72 & 63,4 & 44,6 \\
\hline $\begin{array}{c}\text { FPC-70 } \\
* H D P\end{array}$ & 510 & 1185 & 555 & 152 & 72 & 69,7 & 48,6 \\
\hline KLW -70 & 510 & 1180 & 555 & 150 & 72 & 76,3 & 53,2 \\
\hline $\begin{array}{c}\text { KLW-70 } \\
* \text { HDP }\end{array}$ & 510 & 1185 & 555 & 152 & 72 & 84,8 & 59,3 \\
\hline
\end{tabular}

*HDP - high-density packaging (HDP) of grains of fine-grained steel fibre concrete

The introduction of micro-dispersed additive made the reaction more effective and fast. This additive compacted the cement concrete, filled the emptiness and improved coupling with filler and fiber. The effect of pores` filling, creating of microparticles of additive, assists to considerable decrease of capillary porosity, permeability and durability of concrete for hardscape.

Leading scientific schools works successfully on series of directions. Firstly, it is long-stapled and dispersed reinforcement, also the decision of the problems in the field of textile concrete. One more direction is increase of efficiency of hardscape - dispersed reinforcement for getting of special viscous concretes. Such concretes are remarkable by the fact, that at appearance of cracks, it is possible to increase a loading on them, because dispersed reinforcement allows to sense it without destruction of material.

One of the actual direction is «inner drift ». In compounds of high-strength concretes there is the tendency to decrease of water-cement ratio. It leads to inner dehydration, as a result, the effect of inner autogenic shrinkage appears. The material tries to shrink and because of forced stress, the cracks appear. It is impossible to influence on the processes, described above, affecting on the concrete outside, but it is possible on the stage of mixing of concrete compound to add super absorbing organic or inorganic in the shape of powder, which are capable to absorb large amount of water and keep it some time, and then, when the process of self-drying is activated, giving this water, neutralize it. This really is so-called «inner drift» (table 2) (Mesherin, 2013, Mesherin, 2013). 
Table 2. Features of composition binding materials depending on composition

\begin{tabular}{|c|c|c|c|c|c|c|c|c|c|c|}
\hline \multirow[t]{2}{*}{$\begin{array}{c}\# \\
\Pi / \Pi\end{array}$} & \multicolumn{3}{|c|}{ Composition, $\%$} & \multirow[t]{2}{*}{$\begin{array}{c}\text { Fineness of } \\
\text { grinding of } \\
\text { cement, } \\
\mathrm{m}^{2} / \mathrm{kg}\end{array}$} & \multirow[t]{2}{*}{$\begin{array}{l}\text { Fineness of } \\
\text { grinding of } \\
\text { sinter, } \mathrm{m}^{2} / \mathrm{kg}\end{array}$} & \multirow[t]{2}{*}{$\mathrm{W} / \mathrm{C}$} & \multirow[t]{2}{*}{$\begin{array}{l}\text { Kind of } \\
\text { grinding }\end{array}$} & \multicolumn{3}{|c|}{$\begin{array}{l}\text { Ultimate strength at } \\
\text { pressing at age, MPa at } \\
\text { age, day. }\end{array}$} \\
\hline & cement & sinter & addition & & & & & 3 & 14 & 28 \\
\hline $1 \mathrm{a}$ & 90 & 10 & - & 500 & 500 & 0,30 & Separate & 45,2 & 60,4 & 80,3 \\
\hline $2 \mathrm{a}$ & 90 & 10 & - & 500 & 500 & 0,280 & Combined & 48,7 & 66,8 & 88,7 \\
\hline $3 a$ & 90 & 10 & 1 & 500 & 500 & 0,225 & Combined & 53,2 & 74,3 & 95,2 \\
\hline
\end{tabular}

Textile- concrete is ecologically clear material, which doesn't require a lot of energy expenses at production. This composite material contains such available components as cement, water, sand, glass fibre and chemical additives. Thin glass fibres, which have high capacity to dispersion are added into concrete in small amount (up to $0,6 \mathrm{~kg} / \mathrm{m} 3$ ) and can hold the formation of cracks on early, plastic stage of it's hardening (Klyuev, et al, 2013, Lesovik, et al, 2013).

\section{Discussion}

For increase of efficiency of hardscape and decrease of their cost price it is necessary to use wide-ranging technogeneous raw materials (Mesherin, 2013).

Considerable reserves of produced rocks, which are actual most of all and can serve as a feed stock for creation of hardscape are concentrated in deposits of Kursk Magnetic Anomaly (KMA) (figure 3,4,5).

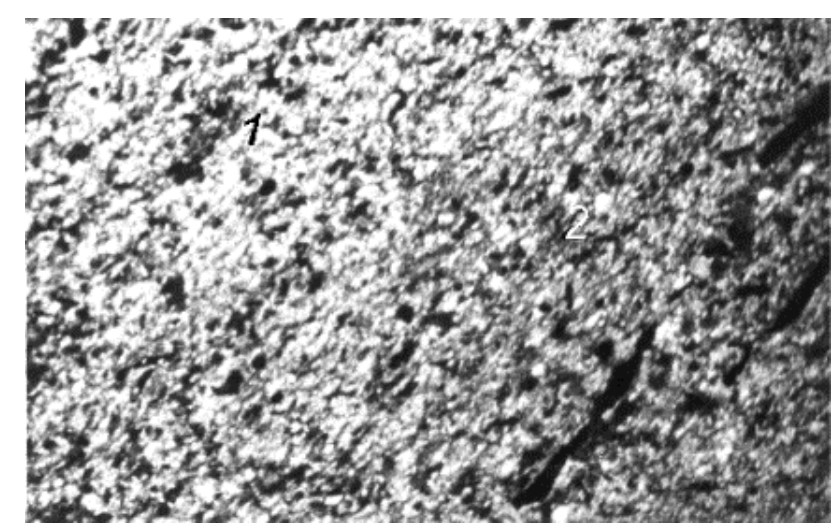

Figure 3. Quartz Schist-micaceous: mica. Nicoli- quartz; $2-1+, \times 100$

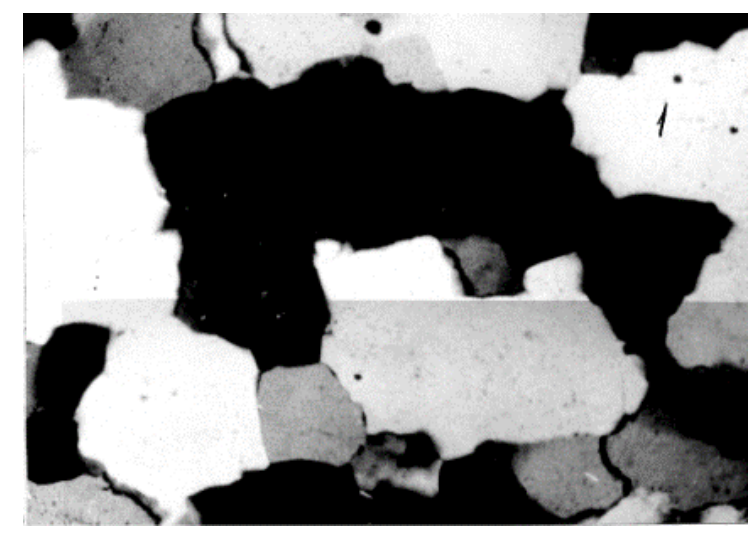

Figure 4. Quartzitic: quartz. Nicoli-1 +, $\times 100$

Among hard rock, assisting in geological structure of KMA, the most valuable raw materials for producing of concrete fillers and production of fine-grained concrete are quartzitic sandstones, quartz porphyry, diorite porphyryte, amphibolites and shales (Lesovik, 1994). 
During the process of technogeneous transformation, at crushing and grinding, particles of quartzitic sandstone are partially amorphized, transforming into active mineral additive (Lesovik, et al, 2013). The analysis of results of physical-mechanical testing of quartzitic sandstones of KMA deposits indicate their high quality (Table 3). (Klyuev, et. al, 2013).

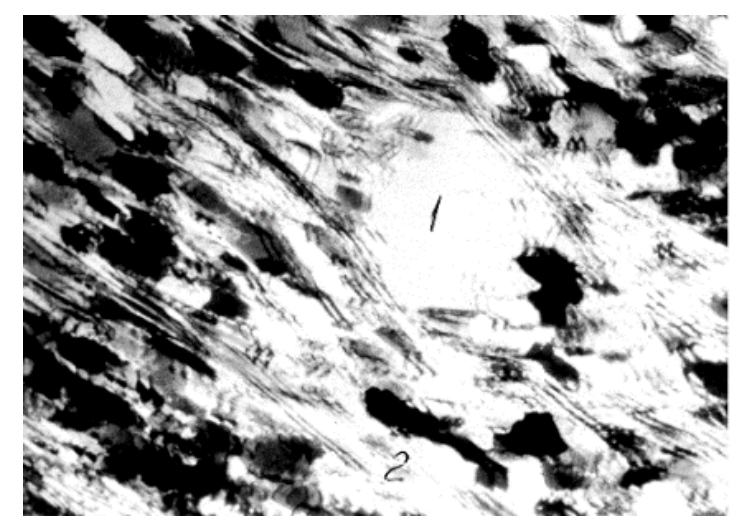

Figure 5. Quartz porphyry recently: 1 - quartz; 2 - Muscovite. Nicoli +, 100

Table 3. Coefficient of quality of siliceous component, depending on microstructure characteristic of quartz

\begin{tabular}{|c|c|c|c|c|c|}
\hline \multirow[t]{3}{*}{ Name of siliceous component } & \multirow{3}{*}{$\begin{array}{c}\text { Coeff. } \\
\text { Quality, } \\
K_{\kappa}\end{array}$} & \multicolumn{4}{|c|}{ Mineral composition } \\
\hline & & \multicolumn{2}{|c|}{ alpha- quarts } & \multicolumn{2}{|c|}{ beta- quarts } \\
\hline & & Turn $\%$ & $\mathrm{OKR}(\mathrm{nm})$ & Turn $\%$ & OKR (nm) \\
\hline $\begin{array}{l}\text { Quartzitic sandstone of Lebedinsky } \\
\text { deposit }\end{array}$ & 1.29 & 65 & & 35 & \\
\hline Sand of Volsky deposit & 1 & 75 & 60 & 25 & 20 \\
\hline Sand of Vyazemsky deposit & 0,84 & 87 & & 13 & \\
\hline
\end{tabular}

Wastes of wet magnetic separation (WMS) of ferruginous quartzites on chemical and mineral compound are close to weak ore quartzites (Lesovik and Kluyev, 2011). This is the valuable raw material for producing of building materials of wide range. At their recurrent enrichment we can get iron-ore concentrate, and from secondary "tail" of enrichment- wall, heat-insulating and acoustic materials of autoclave hardening.

\section{Conclusion}

So, siftings of crushing of quartzitic sandstone of KMA and "tails" have different mineral compound (besides quarts, large content of feldspar, mica, ore minerals are observed). Besides quarts, minerals can participate independently in hydrothermal reactions with binding materials, forming the connections and making a contribution into formation of structure of new formation. For estimation of quality of filler of fine-grained concrete, the compounds of concrete mixtures were developed, mobility and ratio of filler and binding material was constant. Portland cement and KLW are applied as binding material, and the filler is fractional sifting of crushing of quartzitic sandstone. The researches of concrete mixtures and concretes on wastes of crushing from quartzitic sandstone of KMA showed that the latter are high-effective fine filler of concretes.

Thereby, wide nomenclature of compounds of fine-grained concrete on compositional binding material with use of quartzitic sandstone and wastes is developed. Further increase of efficiency is realized at the expense of optimization of microstructure by means of fibers.

The compound of fine-grained fiber-concrete on compositional binding material has high physical and mechanical deformation and exploitation characteristics.

This fact is explained by the best spatial package of particles in produced composite and peculiarities of structure formation. The use of composite binding material and micro-dispersed additive with active surface accelerates the process of synthesis of new formations, which consists of period decrease of the structure formation- at the expense of binding of calcium hydroxide (forming at alit gydration), and formation of compact microstructure of composite. 
In combination of modern methods of analysis and technologies of building materials, these approaches reveal the way for purposeful development of innovative high-technology composites on the basis of cement for production of hardscape. Optimization of concrete structure on micro-, nano- level allowed to get $80 \%$ fine-grained fiber-concretes for industry wastes. So, fiber-concrete is related to green composites.

At the further investigation, similar new types of concrete will be revolutionary for area of planning, design and any construction of designs, and also in the field of repair and strengthening of buildings and constructions.

\section{References}

Burgo, M. O., Palacions, M., Rivilla, P., \& Puertas, F. (2012). Compatibility between superplasticizer admixtures and cements with mineral additions. Constriction and building materials, 31, 652-658.

Corinaldesi V., \& Mariconi G. (2012). Mechanical and thermal evolution of Ultra High Performance Fiber Reinforced Concretes for engineering applications. Constriction and building materials, 26(1), 289-294. http://dx.doi.org/10.1016/j.conbuildmat.2011.06.023

El-Died, A. S., \& Reda, T. M. M. (2012). Flow characteristics and acceptance criteria of fiber-reinforced self-compacted concrete (FR-SCC). Constriction and building materials, 27(1), 585-596.

Ferrara Liberato, Bamonte Patrick, Caverzan Alessio, Musa Abdisa, Sanal Irem. (2012). Comprehensive methodology to test the performance of Steel Fibre Reinforced Self-Compacting Concrete (SFR-SCC). Constriction and building materials, 37, 406-424. http://dx.doi.org/10.1016/j.conbuildmat.2012.07.057

Kluyev, S. V., Kluyev, A. V., Lesovik, R. V., \& Netrebenko, A. V. (2013). High Strength Fiber Concrete for Industrial and Civil Engineering. World Applied Sciences Journal, 24(10), 1280-1285.

Lesovik V. S. (2013). Architectural geonics. Look in the future. Vestnik Volgasy, 31(50)(1), 131-136.

Lesovik V. S., Zagorodnuk L. H., Shkarin A. V., Belikov D. A., \& Kuprina A. A. (2013). Creating Effective Insulation Solutions, Taking into Account the Law of Affinity Structures in Construction Materials. World Applied Sciences Journal, 24(11), 1496-1502.

Lesovik, V. S. (1994). Genetic basis of energy saving in industry of building materials. Building, 7(8), 96-100.

Lesovik, V. S. (2012). Decrease of power-intensity of production of building materials at the expense of energy use of geological and technogeneous processes. Weimar:. Ibaus. Internationale Baustofftagung.

Mesherin, V. (2013). Novel cement-based composites for the strengthening and repair of concrete structures. Construction and Building Materials, 41, 365-373.

Mesherin, V. S. (2013). Innovation technologies increased technical characteristics of concrete to the level, which was considered impossible. Building: new technologies - new equipment, 1, 48-50. http://dx.doi.org/10.1016/j.conbuildmat.2012.11.117

Mesherin, V., \& Reinhardt, W. H. (2012). Application of superabsorbent polymers in concrete construction. RILEM State of the Art Reports, 2.

Nikolaevskaya, I. A. (2002). Accomplishment of territories. Moscow: Academy skill, pp: 268.

Ponikiewski, T. (2012). The influence of steel fibers on the rheological properties of SCC. Silesian UnivesityTechnology. Gliwice BFT Int, 78(8), 42-44, 46-51.

Rings, K. H., Kolczyk, H., \& Losch. (2006). P.: SCC: Grenzen der Betonzusammensetzung. Beton, 7(8), 357-362.

Rodriguez V. I., Aguado de Cea Antonio, de Sensale Gemma Rodriguez. (2012). Self-compacting concrete of medium characteristic strength. Constriction and building materials, 30, 776-786. http://dx.doi.org/10.1016/j.conbuildmat.2011.12.070

Venkateswara, R. S., Venkateswara, R. S, Seshagiri, R. M. V., Ramaseshu, D., Rathish, K. P. (2012). Department performance of self-compacting concrete. Department of Civil Engineering, NIT Warangal, AP. Mag. Concr.Res, 64(11), 1005-1013.

\section{Copyrights}

Copyright for this article is retained by the author(s), with first publication rights granted to the journal.

This is an open-access article distributed under the terms and conditions of the Creative Commons Attribution license (http://creativecommons.org/licenses/by/3.0/). 